\title{
Article/Artigo
}

\section{Factors associated with Leishmania chagasi infection in domestic dogs from Teresina, State of Piauí, Brazil}

\author{
Fatores associados à infecção por Leishmania chagasi em cães domiciliados de Teresina, \\ Estado do Piauí, Brasil
}

\section{João Pereira da Silva ${ }^{1}$, Guilherme Loureiro Werneck ${ }^{2}$, Emanuelle Cardoso Macedo ${ }^{3}$, Hanny de Carvalho ${ }^{4}$ and Maria do Socorro Pires e Cruz ${ }^{3}$}

\begin{abstract}
Introduction: Many studies have evaluated risk factors for human visceral leishmaniasis, but few have focused on the infection among dogs. The objective of this study was to assess the association between peridomestic socioeconomic and environmental factors and the presence of dogs seropositive for Leishmania chagasi in the City of Teresina, Brazil. Methods: This case-control study was based on the results of a routine seroepidemiological survey among domestic dogs carried out in 2007. Serological tests were performed by means of indirect immunofluorescence antibody test. All dwellings in which at least one seropositive dog was detected were considered cases, and controls were a random sample of dwellings in which only seronegative dogs were identified. Associations between variables were expressed as odds ratios (OR) and their respective 95\% confidence intervals (95\% CI) estimated using multivariate logistic regression. Results: Dwellings with a history of dogs removed by the visceral leishmaniasis control program in the last 12 months had five-fold higher odds of having at least one seropositive dog as compared with dwellings having no history of dog removal $(\mathrm{OR}=5.19 ; 95 \% \mathrm{CI}=3.20-8.42)$. Dwellings with cats had $58 \%$ increased odds of dog infection as compared with those having no cats $(\mathrm{OR}=1.58 ; 95 \% \mathrm{CI}=1.01-2.47)$. Conclusions: Identification of factors associated with canine visceral leishmaniasis might be used for the delimitation of areas of higher risk for human visceral leishmaniasis, since infection in dogs generally precedes the appearance of human cases.
\end{abstract}

Keywords: Canine visceral leishmaniasis. Risk factors. Epidemiology. Case-control study. Epidemiological surveillance.

\section{RESUMO}

Introdução: Diversos estudos avaliaram fatores de risco para leishmaniose visceral humana, mas poucos focalizaram a infecção canina. O objetivo deste estudo é avaliar a associação entre condições sócio-ambientais peridomiciliares e a presença de cães sorologicamente positivos para Leishmania chagasi em Teresina, Brasil. Métodos: Estudo caso-controle baseado nos resultados de inquérito soroepidemiológico de rotina entre cães domésticos no ano de 2007. O exame sorológico foi realizado por meio de reação de imunofluorescência indireta. Foram consideradas como casos todas as residências que albergassem pelo menos um cão soropositivo, enquanto o grupo controle correspondeu a uma amostra aleatória das residências onde somente cães soronegativos foram registrados. Associações entre as variáveis foram expressas por meio da razão de chance ou odds ratio (OR) e respectivos intervalos de 95\% de confiança (IC95\%) estimados mediante regressão logística multivariada. Resultados: Residências com história de pelo menos um cão recolhido pelo programa de controle da leishmaniose visceral nos últimos 12 meses apresentaram chance cerca de 5 vezes mais alta de terem cães infectados em comparação com residências sem história de cães removidos no período $(\mathrm{OR}=5,19 ; \mathrm{IC} 95 \%=3,20-8,42)$. Residências com presença de gatos apresentaram chance $58 \%$ mais alta de terem cães infectados em comparação com aquelas sem gatos $(\mathrm{OR}=1,58 ; \mathrm{IC} 95 \%$ = 1,01-2,47). Conclusões: Aidentificação de fatores associados à leishmaniose visceral canina pode ser útil para a delimitação de áreas sob maior risco para leishmaniose visceral humana, na medida em que a infecção canina geralmente precede a ocorrência de casos humanos. Keywords: Leishmaniose visceral canina. Fatores de risco. Epidemiologia. Estudos casocontrole. Vigilância epidemiológica.

1. Gerência de Controle de Zoonoses, Fundação Municipal de Saúde, Teresina, PI. 2. Departamento de Epidemiologia, Instituto de Medicina Social, Universidade do Estado do Rio de Janeiro, Rio de Janeiro, RJ. 3. Programa de Pós-Graduação em Ciência Animal, Centro de Ciências Agrárias, Universidade Federal do Piauí, Teresina, PI. 4. Núcleo de Educação a Distância, Universidade Estadual do Piauí, Teresina, PI. Address to: Dr. Guilherme Loureiro Werneck. Dept ${ }^{\circ}$ de Epidemiologia/IMS/UERJ. Rua São Francisco Xavier 524/7 $7^{\circ}$ andar, Bloco D, Maracanã, 20559-900 Rio de Janeiro, RJ, Brasil.

Phone: 5521 2334-0235; Fax: 5521 2334-2152

e-mail: gwerneck@nesc.ufrj.br

Received in 21/08/2011

Accepted in 10/01/2012

\section{INTRODUCTION}

Visceral leishmaniasis (VL) is a neglected disease endemic to around 65 countries, with an estimated incidence of 500,000 new cases and 59,000 deaths annually ${ }^{1}$. In Brazil, it is caused by the protozoan parasite Leishmania chagasi (syn. Leishmania infantum) and is transmitted by phlebotomine sandflies of the genus Lutzomyia. This is a severe disease, with few therapeutic options and showing a case-fatality rate of around 5\%, even if adequately treated ${ }^{2}$.

Historically recognized as a rural disease, VL has emerged alongside a continuous process of urbanization that has been recorded in Brazil since the beginning of the 1980s. The first documented urban epidemic in the country took place in Teresina, State of Piauí ${ }^{3}$. New epidemics were later described in the cities of Natal, State of Rio Grande do Norte, and São Luis, State of Maranhão, both in the northeast region of the country $y^{4,5}$. Subsequently VL disseminated to other regions of Brazil2 .

The main vector of VL in Brazil is the phlebotomine sandfly Lutzomyia longipalpis, found both in natural ecotopes and in the rural and urban environments, close to domestic animals and human dwellings ${ }^{6}$. This vector adapts easily to the peridomestic environment, particularly in poor neighborhoods located in the outskirts of the cities, exploiting the accumulation of organic matter generated by domestic animals and inadequate sanitation ${ }^{6,7}$.

The epidemiologic panorama does not leave any doubts about the severity of the situation and the evident geographic spread of VL. From 1980 to 2008 , more than 70,000 cases of VL were notified in Brazil, causing more than 3,800 deaths ${ }^{8}$.

Visceral leishmaniasis is a neglected disease of neglected populations. Poverty, migration, unplanned land occupation in urban areas, environmental damage, substandard living conditions, and malnutrition are just some of the many determinants of its occurrence. The World 
Health Organization recognizes the absence of effective tools for disease elimination, despite all the efforts in the Indian subcontinent, where the infection is transmitted from person to person through the bite of the vector. In this specific case, treatment of human cases might contribute to reduce transmission. In Brazil, however, where transmission is zoonotic, treatment has basically a curative role ${ }^{1}$.

The domestic dog has been incriminated as the main reservoir of the parasite in the urban environment, but control measures based on culling infected dogs have not been shown to be effective in containing the spread of the disease throughout the country'.

Many studies have been undertaken with the objective of evaluating factors associated with human infection with L. chagasi, but few have focused on canine infection, particularly in Brazil. Anyhow, the latter studies have focused mostly on dog characteristics such as age, sex, breed, size, hair, clinical signs, and infestation with ectoparasites as factors associated with canine infection ${ }^{10-12}$. Although dog characteristics are important markers of infection and can be used to recognize more susceptible groups of dogs, most of these features cannot be modified and, consequently, are not useful as targets for interventions. Conversely, the assessment of socioeconomic and environmental risk factors for canine leishmaniasis might be an important approach not only to increase our knowledge on the dynamics of transmission of infection but also to identify new potential targets for controlling the spread of VL in urban areas.

Thus, the objective of this study was to assess the association between peridomestic socioeconomic and environmental factors and the presence of dogs seropositive for L. chagasi in the City of Teresina, Brazil.

\section{METHODS}

\section{Study area and study design}

This was a case-control study to examine the association between peridomestic socioeconomic and environmental factors and the presence of canine infection with L. chagasi. The study was carried out in 2007, in the Angelim neighborhood, located in the urban periphery of the City of Teresina, State of Piauí, Brazil. The neighborhood, with 10 villages, registered more than 100 cases of human VL between the years 1996 and 2005, which corresponds to almost 10\% of the total cases recorded in the city during the same period.

\section{Definition of cases and controls}

Seropositive and seronegative dogs were identified by reviewing the reports of a routine seroepidemiological survey among domestic dogs carried out in 2007 in the Angelim neighborhood by the Visceral Leishmaniasis Control Program (VLCP) of the Zoonosis Control Center of the Teresina City Health Department. Serological tests were performed by means of indirect immunofluorescence antibody test (IFAT) using a canine leishmaniasis kit supplied by Bio-Manguinhos, FIOCRUZ, Rio de Janeiro. A positive reaction was considered if promastigote membrane fluorescence was observed at a serum dilution of 1:40. All dwellings in which at least one seropositive dog was detected were considered cases, and controls were a random sample of dwellings in which only seronegative dogs were identified.

\section{Sample size}

A sample size of 600 dwellings ( 109 cases and 491 controls) gives a statistical power $(1-\beta)$ of $80 \%$ to detect as significant an odds ratio
$(\mathrm{OR}) \geq 2$, for exposures with a relative frequency of $20 \%$ in control dwellings, considering an $\alpha$ error of 5\%.

\section{Data collection and measurements}

Owners of the selected dwellings were interviewed using a semi-structured questionnaire covering questions on literacy of the household head, history of VL in the household, water supply, sewage disposal, presence of animal sheds (kennel; chicken, cattle, or pig sheds), presence of cats in the house, presence of chickens or ducks or geese in the house or in the peridomestic environment, presence of other animals in the house or in the peridomestic environment (pigs, sheep, goats, and horses), history of dogs removed by the VLCP in the last 12 months, and backyard with accumulated rubbish and insecticide spraying in the house in the previous 12 months (Table $\mathbf{1}$ ).

\section{Statistical analysis}

Initially the distribution of the characteristics of the dwellings with and without infected dogs was described. Those variables showing differences in their distribution, comparing dwellings with and without infected dogs at a $10 \%$ level $(\mathrm{p} \leq 0.10)$, were selected for multivariate analysis.

Multivariate analysis was performed by means of logistic regression models. Associations between variables were expressed as ORs and their respective $95 \%$ confidence intervals (95\% CI). A p-value of 0.05 was used as the criterion for assessing statistical significance of results. Statistical analyses were performed using STATA 9.2 (STATACorp., College Station, TX).

\section{Ethical considerations}

This research used data from a routine seroepidemiological survey carried out in 2007 in the Angelim neighborhood by the VLCP of the Zoonosis Control Center of the Teresina City Health Department. The use of these data for this research, without identification of the dog owners and with assurance of confidentiality, was granted by the chief of the Department of Assistential Action of the Teresina City Health Department.

\section{RESULTS}

Table 1 shows the distribution of the characteristics of the dwellings with and without infected dogs. There was no statistically significant difference $(\mathrm{p} \leq 0.05)$ between case and control dwellings regarding literacy of the household head, history of VL in the household, water supply, presence of animal sheds (kennel; chicken, cattle, or pig sheds), presence of chickens or ducks or geese in the house or in the peridomestic environment, presence of other animals in the house or in the peridomestic environment (pigs, sheep, goats, and horses), and backyard with accumulated rubbish and history of insecticide spraying in the house in the previous 12 months. As compared with dwellings having only seronegative dogs, the houses with at least one infected dog were more frequently connected to inadequate sewage disposal system $(p=0.034)$. These dwellings were also more frequently inhabited by cats $(\mathrm{p}=0.025)$ and had a history of dogs removed by the VLCP in the last 12 months ( $<<0.001)$.

Table 2 shows the results of multivariate analysis in which the association between each exposure variable and the outcome was adjusted for the effect of the other variables in the table. A statistically significant association was observed only for the presence of cats 
TABLE 1 - Distribution of the characteristics of dwellings with and without infected dogs, Teresina, State of Piauí, Brazil, 2007.

\begin{tabular}{|c|c|c|c|}
\hline Characteristics & $\begin{array}{c}\text { Dwellings with only } \\
\text { seronegative dogs } \\
(\%)\end{array}$ & $\begin{array}{c}\text { Dwellings with at } \\
\text { least one seropositive dog } \\
(\%)\end{array}$ & p-value \\
\hline \multicolumn{4}{|l|}{ Literacy of the household head } \\
\hline only elementary & 55.9 & 63.2 & 0.171 \\
\hline higher than elementary & 44.1 & 36.8 & \\
\hline \multicolumn{4}{|l|}{ History of VL in the household } \\
\hline yes & 3.1 & 3.7 & \\
\hline \multicolumn{4}{|l|}{ Water supply system } \\
\hline connected to public system & 86.1 & 84.4 & 0.636 \\
\hline unconnected & 13.9 & 15.6 & \\
\hline \multicolumn{4}{|l|}{ Sewage disposal } \\
\hline public sanitation system/septic pit latrines & 91.8 & 85.3 & 0.034 \\
\hline \multicolumn{4}{|c|}{ Presence of animal sheds (kennel; chicken/cattle/pig sheds) } \\
\hline no & 81.3 & 74.3 & 0.098 \\
\hline yes & 18.7 & 25.7 & \\
\hline \multicolumn{4}{|l|}{ Presence of cats in the house } \\
\hline no & 65.6 & 54.1 & 0.025 \\
\hline yes & 34.4 & 45.9 & \\
\hline \multicolumn{4}{|c|}{ Presence of chickens, ducks, or geese in the house or in the peridomestic environment } \\
\hline no & 80.8 & 73.4 & 0.085 \\
\hline yes & 19.2 & 26.6 & \\
\hline \multicolumn{4}{|c|}{ Other animals in the house or in the peridomestic environment (pigs, sheep, goats, and horses) } \\
\hline no & 97.1 & 97.2 & 0.955 \\
\hline yes & 2.9 & 2.8 & \\
\hline \multicolumn{4}{|c|}{ Dogs removed by the Visceral Leishmaniasis Control Program in the last 12 months } \\
\hline no & 89.0 & 58.7 & $<0.001$ \\
\hline no & 95.9 & 91.7 & 0.065 \\
\hline yes & 4.1 & 8.3 & \\
\hline \multicolumn{4}{|c|}{ Insecticide spraying in the house in the previous 12 months } \\
\hline no & 42.2 & 34.3 & 0.126 \\
\hline yes & 57.8 & 65.7 & \\
\hline
\end{tabular}

TABLE 2 - Multivariate adjusted odds ratio and their $95 \%$ confidence intervals for the association between canine Leishmania chagasi infection and selected variables, Teresina, State of Piauí, Brazil, 2007*.

\begin{tabular}{|c|c|c|c|c|c|}
\hline Characteristics & $\begin{array}{l}\text { Dwellings with only } \\
\text { seronegative dogs (n) }\end{array}$ & $\begin{array}{l}\text { Dwellings with at least } \\
\text { one seropositive } \operatorname{dog}(n)\end{array}$ & $\mathbf{O R}^{\#}$ & $95 \% \mathrm{CI}$ & p-value \\
\hline \multicolumn{6}{|l|}{ Sewage disposal } \\
\hline public sanitation system/septic pit latrines & 451 & 93 & 1 & & 0.072 \\
\hline pit latrines/open air & 40 & 16 & 1.84 & $0.95-3.60$ & \\
\hline \multicolumn{6}{|c|}{ Presence of animal sheds (kennel; chicken, cattle, or pig sheds) } \\
\hline no & 396 & 81 & 1 & & 0.479 \\
\hline yes & 91 & 28 & 1.23 & $0.70-2.15$ & \\
\hline \multicolumn{6}{|l|}{ Presence of cats in the house } \\
\hline no & 322 & 59 & 1 & & 0.046 \\
\hline yes & 169 & 50 & 1.58 & $1.01-2.47$ & \\
\hline \multicolumn{6}{|c|}{ Presence of chickens, ducks, or geese in the house or in the peridomestic environment } \\
\hline no & 395 & 80 & 1 & & 0.381 \\
\hline yes & 94 & 29 & 1.28 & $0.74-2.21$ & \\
\hline \multicolumn{6}{|c|}{ Dogs removed by the Visceral Leishmaniasis Control Program in the last 12 months } \\
\hline no & 436 & 64 & 1 & & $<0.001$ \\
\hline yes & 54 & 45 & 5.19 & $3.20-8.42$ & \\
\hline \multicolumn{6}{|l|}{ Backyard with accumulated rubbish } \\
\hline no & 471 & 100 & 1 & & 0.177 \\
\hline yes & 20 & 9 & 1.87 & $0.75-4.62$ & \\
\hline
\end{tabular}

OR: odds ratio; 95\%CI: 95\% confidence intervals. ${ }^{*}$ Full data were not available for every dwelling; \#Adjusted for the other variables in the table. 
and a history of dogs removed by the VLCP in the last 12 months. Dwellings with a history of dogs removed by the VLCP in the last 12 months before the interview had five-fold higher odds of having at least one seropositive dog as compared with dwellings having no history of dog removal in the same period. Dwellings with cats had $58 \%$ increased odds of dog infection as compared with dwellings with no cats.

\section{DISCUSSION}

Gaining knowledge about the factors involved in the dynamics of transmission of VL in urban and periurban settings is still a challenge for public health. Little is known about the variables that determine the disease distribution in these environments, particularly concerning canine infection.

In Brazil, the main strategies used for interrupting VL transmission are vector control with insecticides and culling of infected $\operatorname{dogs}{ }^{13}$. However, these measures have been found to be insufficient to contain disease dissemination ${ }^{8}$. Among the control measures evaluated in this study, the use of insecticide spraying in the last 12 months did not show a statistically significant association with canine infection. However, the existence of a seropositive dog was five times more common in dwellings which had a dog removed by the VLCP in the last 12 months. This apparently counterfactual finding actually suggests that the strategy of culling infected dogs is not effective in interrupting transmission, leaving intact the basic condition that allows the appearance of new cases of canine infection with $L$. chagasi. In that sense, this control strategy needs to be reviewed in light of the various scientific evidence showing that its effectiveness is limited to interrupting the transmission cycle in urban settings, in addition to being socially controversial ${ }^{9}$.

Although the presence of animals in the peridomestic environment and the maintenance of animal sheds have been described as factors associated with canine infection ${ }^{14-16}$, in this study only the presence of cats showed a statistically significant association with the prevalence of dog seropositivity. Infection with $L$. chagasi in cats has been described in several studies, but it still is debatable whether these animals might act as reservoirs or are only eventual hosts ${ }^{17-19}$. Alternatively, these animals might favor the maintenance of the transmission cycle of canine infection by attracting sandflies, as has been described for other animals ${ }^{10,14,15}$. If this hypothesis could be corroborated by other studies, the importance of cats should not be minimized, since they share the same environment with the domestic dog. In any case, this finding highlights the need for specific studies on the potential role of cats in the transmission of L. chagasi in urban settings.

Studies have demonstrated the association between socioeconomic factors, such as poor sanitation, low literacy, and low income, and the occurrence of human $\mathrm{VL}^{1,20}$, but most studies on canine VL have overlooked this question. In a cross-sectional study, Coura-Vital et al. ${ }^{21}$ found low income of the owner to be an independent factor associated with canine infection. In this study, however, the occurrence of canine VL was not significantly associated with the literacy of the household head, water supply, and the presence of rubbish in the backyard. Similarly, Azevedo et al. ${ }^{16}$ did not find garbage accumulation in the residence and family income to be associated with canine infection. In our study, the odds of canine infection were $80 \%$ higher in dwellings with an inadequate sewerage system, but this association was only marginally significant $(p=0.072)$. Consistent with this result, Costa et al. ${ }^{22}$ verified the association between an inadequate sewerage system and a higher risk of human VL.

A limitation of this study is the insufficient statistical power to detect as significant ORs $<2$, which correspond to most of the associations identified. The study was restricted to a sole neighborhood of Teresina in which the life patterns and peridomestic environmental characteristics are somewhat homogeneous, contributing to the identification of weak associations that could only be detected as significant with substantially larger sample sizes. Subsequent studies on this theme should broaden their geographical scope to incorporate greater social and environmental heterogeneity. This would probably disclose stronger associations that would be detected as significant with equal or even lower sample sizes as that used in the present study. Another weakness of our study is the absence of information on landscape features, such as vegetation cover and land use, which might well be important risk factors for canine infection. Other studies have pointed out the role of micro-environmental characteristics, such as the presence of dense vegetation in the neighborhood and proximity to wooded areas and forests, in increasing the risk of transmission ${ }^{12,14,23,24}$. Again, the option of studying just a single neighborhood made it difficult to observe enough variation in the landscape in order to include such dimension in our analysis. The use of only IFAT as the criterion for defining a dog as infected or not is also a shortcoming of the study, since both the sensitivity and the specificity of this test are far from ideal. However, since the misclassification error due to this type of improper case definition would be non-differential, one could infer that the potential impact of such bias would lead the OR in the direction of the null association ${ }^{25}$. Therefore, if this bias really occurred, then the true ORs would be higher than those presented in this study.

Studies about risk factors for canine VL in endemic areas are scanty in the literature but are essential for providing a better understanding of the disease dynamics in urban settings. The identification of such factors might contribute to the delimitation of areas of higher risk for human VL occurrence, since infection in dogs generally precedes the appearance of human cases ${ }^{26}$. Thus, they might be a good earlier marker for transmission risk and could be used to inform control actions for VL. In any case, more studies, preferentially using a longitudinal approach, are needed to disentangle the complex network of factors that might be involved in the transmission of L. chagasi among dogs and humans in endemic areas.

\section{ACKNOWLEDGMENTS}

The authors thank the chief of the Department of Assistential Action of the Teresina City Health Department for allowing the use of the data for this research. We also thank the community health professionals Ricardo, Marilene, Marcos, Edson, and Assis for their assistance during data collection.

\section{CONFLICT OF INTEREST}

The authors declare that there is no conflict of interest.

\section{FINANCIAL SUPPORT}

Financial support was provided by Conselho Nacional de Desenvolvimento Científico e Tecnológico (CNPq) and Fundação de Amparo à Pesquisa do Estado do Piauí (FAPEPI). 


\section{REFERENCES}

1. World Health Organization. Control of the Leishmaniases. Report of a meeting of the WHO Expert Committee on the Control of Leishmaniases. Geneva: World Health Organization; 2010.

2. Maia-Elkhoury AN, Alves WA, Sousa-Gomes ML, Sena JM, Luna EA. Visceral leishmaniasis in Brazil: trends and challenges. Cad Saude Publica 2008; 24:2941-2947.

3. Costa CHN, Pereira HF, Araújo MV. Epidemia de leishmaniose visceral no estado do Piauí, Brasil, 1980-1986. Rev Saude Publica 1990; 24:361-372.

4. Jerônimo SM, Oliveira RM, Mcckay S, Costa RM, Sweet J, Nascimento ET, et al. An urban outbreak of visceral leishmaniasis in Natal, Brazil. Trans Royal Soc Trop Med Hyg 1994; 88:386-388.

5. Silva AR, Viana GMC, Varonil C, Pires B, Nascimento MDSD, Costa JML. Leishmaniose visceral (Calazar) na ilha de São Luís, Maranhão, Brasil: evolução e perpectivas. Rev Soc Bras Med Trop 1997; 30:359-368.

6. Rangel EF, Vilela ML. Lutzomyia longipalpis (Diptera, Psychodidae, Phlebotominae) and urbanization of visceral leishmaniasis in Brazil. Cad Saude Publica 2008; 24:2948-52.

7. Aguiar GM, Medeiros WM, Marco TS, Santos SC, Gambardella S. Ecologia dos flebotomíneos da Serra do Mar, Itaguaí, Estado do Rio de Janeiro, Brasil. I - A fauna flebotomínica e prevalência pelo local e tipo de captura (Diptera, Psychodidae, Phlebotominae). Cad Saude Publica 1996; 12:195-206.

8. Werneck GL. Geographic spread of visceral leishmaniasis in Brazil. Cad Saude Publica 2010; 26:644-645.

9. Romero GA, Boelaert M. Control of visceral leishmaniasis in Latin America - a systematic review. PLoS Negl Trop Dis 2010; 4:e584.

10. Oliveira LC, Araújo RR, Alves CR, Mouta-Confort E, López JA, MendonçaLima FW. Seroprevalence and risk factors for canine visceral leishmaniasis in the endemic area of Dias D’Avila, State of Bahia, Brazil. Rev Soc Bras Med Trop 2010; 43:400-404.

11. Paz GF, Ribeiro MF, Magalhães DF, Sathler KP, Morais MH, Fiúza VO, et al. Association between the prevalence of infestation by Rhipicephalus sanguineus and Ctenocephalides felis felis and the presence of anti-Leishmania antibodies: A case-control study in dogs from a Brazilian endemic area. Prev Vet Med 2010; 97:131-133.

12. Rondon FC, Bevilaqua CM, Franke CR, Barros RS, Oliveira FR, Alcântara AC, et al. Cross-sectional serological study of canine Leishmania infection in Fortaleza, Ceará state, Brazil. Vet Parasitol 2008; 155:24-31.
13. Ministério da Saúde. Manual de vigilância e controle da leishmaniose visceral. Brasília: Secretaria de Vigilância em Saúde. Departamento de Vigilância Epidemiológica; 2006.

14. Cabrera MA, Paula AA, Camacho LA, Marzochi MC, Xavier SC, Silva AV, et al. Canine visceral leishmaniasis in Barra de Guaratiba, Rio de Janeiro, Brazil: assessment of risk factors. Rev Inst Med Trop Sao Paulo 2003; 45:79-83.

15. Moreira Jr ED, Souza VM, Sreenivasan M, Lopes NL, Barreto RB, Carvalho LP. Peridomestic risk factors for canine leishmaniasis in urban dwellings: new findings from a prospective study in Brazil. Am J Trop Med Hyg 2003; 69:393-397.

16. Azevedo MA, Dias AK, Paula HB, Perri SH, Nunes CM. Avaliação da leishmaniose visceral canina em Poxoréo, Estado do Mato Grosso, Brasil. Rev Bras Parasitol Vet 2008; 17:123-127.

17. Maroli M, Pennisi MG, Di Muccio T, Khoury C, Gradoni L, Gramiccia M. Infection of sandflies by a cat naturally infected with Leishmania infantum. Vet Parasitol 2007; 145:357-360.

18. Martín-Sánchez J, Acedo C, Muñoz-Pérez M, Pesson B, Marchal O, MorillasMárquez F. Infection by Leishmania infantum in cats: epidemiological study in Spain. Vet Parasitol 2007; 145:267-273.

19. Silva AV, Souza-Cândido CD, Pita-Pereira D, Brazil RP, Carreira JC. The first record of American visceral leishmaniasis in domestic cats from Rio de Janeiro, Brazil. Acta Trop 2008; 105:92-94.

20. Alvar J, Yactayo S, Bern C. Leishmaniasis and poverty. Trends Parasitol 2006 22:552-557.

21. Coura-Vital W, Marques MJ, Veloso VM, Roatt BM, Aguiar-Soares RD, Reis LE, et al. Prevalence and factors associated with Leishmania infantum infection of dogs from an urban area of Brazil as identified by molecular methods. PLoS Negl Trop Dis 2011; 5:e1291.

22. Costa CH, Werneck GL, Rodrigues Jr L, Santos MV, Araújo IB, Moura LS, et al. Household structure and urban services: neglected targets in the control of visceral leishmaniasis. Ann Trop Med Parasitol 2005; 99:229-236.

23. Silva AV, Paula AA, Cabrera MA, Carreira JC. Leishmaniose em cães domésticos: aspectos epidemiológicos. Cad Saude Publica. 2005; 21:324-328.

24. Almeida Ado B, Faria RP, Pimentel MF, Dahroug MA, Turbino NC, Sousa VR Inquérito soroepidemiológico de leishmaniose canina em áreas endêmicas de Cuiabá, Estado de Mato Grosso. Rev Soc Bras Med Trop 2009; 42:156-159.

25. Szklo M, Nieto FJ. Epidemiology: beyond the basics. Gaithersburg (MD): Aspen; 2000.

26. Oliveira CL, Assunção RM, Reis IA, Proietti FA. Spatial distribution of human and canine visceral leishmaniasis in Belo Horizonte, Minas Gerais State, Brazil, 1994-1997. Cad Saude Publica 2001; 17:1231-1239. 